PRZEGLĄD BIBLIOTECZNY 2020

e-ISSN 2545-2487

BOŻENA JASKOWSKA

Institute of Information Sciences

Pedagogical University of Cracow

e-mail: bozena.jaskowska@up.krakow.pl

ORCID: 0000-0002-7484-3161

\title{
ORGANIZATIONAL FLEXIBILITY OF ACADEMIC LIBRARIES IN A VUCA REALITY: THE EXAMPLE OF THE FUNCTIONING OF LIBRARIES DURING THE COVID-19 EPIDEMIC
}

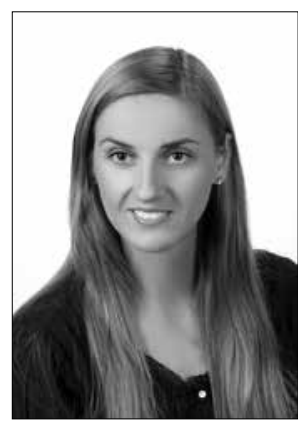

Assistant Professor at Pedagogical University of Cracow. Long-term (2010-2020) director of the University of Rzeszow Library and member of the Executive Council of the Conference of Directors of Academic Libraries of Polish Schools (2012-2020). PhD in Humanities (UW, 2007), graduate of MBA IT studies (ALK, 2012). Scientific specialization: information architecture; information user research; User Centered Design, User Expierience, library management and marketing. Publications: Wojciechowska M., Kamińska J., Żołędowska-Król B., Jaskowska B. (2019). Leksykon zarządzania i marketingu $w$ bibliotekarstwie. Warszawa: SBP; Jaskowska B. (2009). Efektywny marketing SEO witryny bibliotecznej. Przeglad Biblioteczny, 77, 229-238.

KEYWORDS: Academic Libraries. Organizational flexibility. COVID-19 outbreak. Lockdown. Remote work. Change management. VUCA.

ABSTRACT: Thesis / purpose of the article - The aim of the article is to present management solutions used in academic libraries in a changing and unpredictable environment, on the example of the functioning of units during the lockdown period caused by the COVID-19 epidemic, which lasted from March 12 to the beginning of June 2020. Research method - Research was conducted among 
the directors of Polish academic libraries using an online survey as a research tool. Results and conclusions - The research analysis shows that academic libraries showed considerable organizational flexibility during the lockdown period, especially in terms of changing duties, forming plans "just in time", extending the scope of services and organizing large-scale remote and rotational work. Some libraries have also changed decision-making processes. This is the first such study of the functioning of academic libraries during the lockdown period.

For years there has been talk about the need for a flexible approach to the management of academic libraries, the ability to quickly adapt to environmental changes and requirements, and an agile approach to processes and tasks. But it seems that only the COVID-19 epidemic and the nearly 3-month lockdown introduced in relation to it in 2020 have made management face the real problems of quick, flexible, and effective introduction of changes to the core operations of their facilities and redefine their current operating philosophy.

The aim of this article is to take a closer look at management practices and solutions, with particular emphasis on the organizational flexibility that was implemented in Polish academic libraries during the lockdown caused by the COVID-19 epidemic. Lockdown is understood as the period from March 12 to the beginning of June 2020. The characterization was carried out on the basis of the author's own research, which was carried out using the sociological method of an online survey as a research tool among the directors of academic libraries in Poland.

\section{THE VUCA REALITY AND THE COVID-19 EPIDEMIC}

In December 2019, the SARS-CoV-2 virus, which appeared in the Chinese city of Wuhan, quickly spread to the entire country and other continents. Since February 2020, the world has not talked about anything other than the "coronavirus" - the rapid spread of the disease, lack of vaccine, high mortality in the elderly or those with comorbidities, information noise and, above all, the lack of preparation of state institutions and the inefficiency of health services turned the event, which up to that point had been perceived as a marginal and local problem of Chinese society, into a powerful global crisis. On March 11, 2020, the World Health Organization declared a pandemic, and experts, virologists, and doctors generally agreed that the wave of further illnesses and fatalities could only be effectively stopped by a strict lockdown. Most governments introduced extensive restrictions on public, social, and economic life. Enterprises, schools, airports, cultural institutions, as well as service and gastronomic premises were closed. Movement restrictions were introduced, borders were closed. Epidemic statistics became more and more disturbing: on April 30, 
2020, over 3 million cases were registered and nearly 218,000 deaths were identified (WHO, 2020), and despite the sanitary restrictions introduced, the epidemic did not end. For companies and institutions, their continued existence depended upon quick and flexible adaptation to the new reality. Many of them - for the first time in their histories, in fact - have now had direct contact with the phenomenon known as VUCA (Worley \& Jules, 2020).

VUCA is an acronym for the following words: Volatility, Uncertainty, Complexity and Ambiguity, which in the military and political environment were first used to describe the changing and turbulent reality that emerged after the end of the Cold War, which then found application in depicting the world in the crisis after the terrorist attack on the World Trade Center in 2001 (VUCA, 2020). Since then, the term VUCA has experienced a kind of renaissance, especially in the concepts of strategic leadership, where it is used to outline the context of functioning and creating models of effective management of organizations (Judek, 2020). What is the reality of VUCA? Volatility (changeability, elusiveness) refers to the dynamics of the conditions for the functioning of an organization (e.g. instability of the legal and economic system, natural disasters, terrorist attacks), which make created plans, procedures or strategies of action quickly obsolete or even inadequate. The greater the volatility, the more perceptible insecurity (Uncertainty) about the future appears, which makes decision-making processes very difficult and forces the preparation of various action scenarios and risk management concepts. Complexity, in turn, has its source in the overlapping of many different areas of activity and in the interpenetration of relationships and influences. It is also in the dynamics of the system, the flood of information and big data, i.e. large, diverse, and variable databases. Such phenomena disrupt the classic cause and effect chain and may additionally hinder planned and effective management. Ambiguity appears in unknown or multi-meaning situations, as well as when not everything can be explained in a simple way on the basis of logic or previous experience (Krawczyńska-Zaucha, 2019).

In the face of the global crisis caused by the COVID-19 epidemic, where each new day brought new surprising news, where many forecasts and scenarios regarding the development of the health, social, and economic situation did not work, where the world was flooded with false information, of which there was so much that the phenomenon has been referred to as infodemic, it seems that there is no other adequate term than VUCA to describe such a changing and turbulent reality. And in the organizations themselves, the ability to flexibly and boldly adapt to unexpected events began to count even more than before.

The reality of VUCA can put leaders into total management stagnation, lure them into the trap of over-control, and influence wrong decisions. The 
discomfort associated with uncertainty may result in abandoning entrepreneurial actions and force one to make conservative or, on the contrary, hasty and ill-considered decisions. For many managers, VUCA may, however, be an opportunity to redefine the organization's goals, method of operation, and human resource management. And thereby to improve the efficiency of operation.

How did Polish academic libraries cope in these new conditions, forced by the COVID-19 epidemic? Have the directors and employees of Polish academic libraries shown flexibility in reorganizing library and information services? How did remote work - not very common so far in the library environment - work? What was the biggest problem and what turned out to be an opportunity? What conclusions were made? These questions, among others, as well as the author's own experiences in the field of academic library management in the aforementioned period, were the basis and inspiration for a closer look at the phenomenon of organizational flexibility of libraries and to undertake the research described in this article.

\section{ORGANIZATIONAL FLEXIBILITY OF ACADEMIC LIBRARIES}

Flexibility, understood as the ability to adapt an organization to the conditions in the environment, is nowadays considered one of the basic criteria of organizational effectiveness (Ziębicki, 2010). In the case of librarianship, this aspect is most often discussed in relation to the flexibility of the organizational structure, which consists in the ability to quickly adapt to changes. Flexible structures efficiently react both to changes originating in the external environment of the library and to those resulting from inside the organization. In this case, flexibility is supported by: delegating powers, reducing the management levels, minimizing formalization and bureaucracy, as well as being sensitive to signals from the environment (Wojciechowska et al., 2018, p. 66).

Flexibility and the related openness to changes and signals from the environment can be considered in several dimensions, which are also confirmed in modern management concepts. In the case of knowledge management and organizational learning, flexibility ensures a continuous flow of knowledge and its effective use to transform the organization. In process management and reengineering, flexibility is associated with the monitoring of signals from the environment and customer satisfaction as the basis for the improvement of organizational processes. Changing one's way of thinking, understanding the environment, and providing adaptive responses are also basic conditions for effective management in the spirit of lean management (Ziębicki, 2010, pp. 390-391). The same is true in the 
case of agile management, where flexibility is the determinant of project implementation. Iterative, incremental approaches to the organization of team work, along with a flexible and interactive forms of activities, arose from the practice of IT project management, where instead of cascading and planned project management there is an emphasis on changes, which are a natural element of project delivery. Agile Manifesto (Manifesto for agile software development), which is the particular mission statement of the creators of this programming philosophy, lists the following pillars of the approach discussed: individuals and interactions (over processes and tools), customer collaboration (over formal arrangements and contract negotiations), working software (over comprehensive and detailed documentation), and responding to changes (over following a plan) (Manifest, 2001). Currently, the agile approach, due to its flexibility, universality, and the possibility of using it in a changing and turbulent environment, is widely used outside the IT environment, e.g. in many areas of business, in the public sector, and in research and development. It is also implemented in library practice (Haricombe, ed., 1998).

C.G. Worley and C. Jules, in the context of analysing the organizational flexibility of companies during the COVID-19 epidemic, point to the need to distinguish so-called "brilliant improvisation" from the repetitive ability to learn and flexible adaptation to the environment. While the first phenomenon, based on creativity, spontaneity, and considerable courage, can bring spectacular effects, they are usually one-off and short-lived. Organizations that care about the long-term agile ability to organize processes must have the ability to constantly learn, test, and consciously implement innovations and novelties. Agility in the case of reality VUCA can support the organization's resistance to turbulence and facilitate flexible introduction of changes to its procedures, as well as be the basis for the practice of so-called "change fluency" as an element of the natural development of an organization (Worley \& Jules, 2020, p. 281).

Already in the 1990s, the importance of implementing a flexible agile approach to the management of academic libraries was being emphasized, to be a response to significant technological, social and organizational changes in higher education. Creativity, innovation, entrepreneurship, the ability to take risks and manage them, as well as the ability to implement changes effectively - these were the features that allowed academic libraries to respond effectively and quickly to the needs of users and to changes in the entire academic ecosystem (Haricombe, ed., 1998). At the beginning of 2020, when in the economic, social and scientific areas the whole world stopped due to the emergence of the virus and the threat it carried to people's health and lives, the organizational flexibility of companies, enterprises and non-profit sector entities became basically the only chance to function effectively in the reality of VUCA. 
As in commercial organizations, also in libraries the key to effective functioning in a turbulent environment is organizational flexibility, the ability to learn and introduce changes. S. O'Connor points to the following areas of library practice which are particularly important in this area: focusing on people, taking into account their experiences and emotions, with a focus on action and on overcoming anxieties and fears; treating change as an ongoing process; clear, understandable, honest communication between stakeholders with an emphasis on commitment, empathy, education and inclusion; treating resistance to change as an opportunity and shaping an organizational culture conducive to change and the introduction of changes to the natural environment of the library's functioning (O'Connor, ed., 2015, pp. 3-18). The deployment of agile practice to implement processes in the library (first in IT projects, then in other areas) is a difficult task, but the benefits obtained confirm the point of taking these actions, which can be seen in the example of the Chalmers Library. The following benefits should be mentioned here: the organization learns all the time, librarians know how to react to changes, how to modify priorities and distribute tasks among themselves, and how to build effective teams, and they are also able to identify risks early and react to them. It is worth adding that the implementation of the agile approach in the library forces employees to open communication and discussion, reveals differences of opinion and makes them think about what is being done and for what purpose, what is indirectly shaped by commitment and a sense of agency (O'Connor, ed. 2015, pp. 97-98). It is therefore emphasized that the success of agile functioning in the library environment depends on the charisma of the leader and the maturity of the team. Librarians need to be aware of the role they and the organization as a whole play in sharing information and disseminating knowledge.

M. Ali and P. Gatiti, listing the most important tasks that scientific libraries should perform during the COVID-19 epidemic, first of all mention: promoting public health awareness by creating and disseminating information on preventive measures; supporting research teams, scientists and lecturers by providing them with the latest research results and necessary literature; and meeting the basic needs of ordinary library users (Ali \& Gatiti, 2020). Another, very important role of librarians in the context of the COVID-19 epidemic is emphasized by S. Naeem and R. Bhatti, who underline that it is the professional information services that bear the responsibility for fighting the massively emerging fake news (Naeem \& Bhatti, 2020). The Infodemic, defined by the World Health Organization as the rapid and immediate spread internationally of various information, including gossip, rumours, and untrustworthy facts, via social media, the Internet, and other communication technologies, is a huge threat (WHO, 2018). People develop fear, insecurity, sometimes aggression, as well as 
distrust of public institutions and improper behaviour that threatens health or life. S. Naeem and R. Bhatti cite the IFLA recommendations according to which the identification of fake news should follow this scheme: checking the source of the information, its author and publication date; verifying it in terms of one's own (biased) beliefs; checking the context of the information and additional sources; reflecting on whether the information is not a joke or a provocation; conducting expert inquiry (Naeem \& Bhatti, 2020). Librarians can support users in principle at each of the mentioned stages of fake news verification.

\section{ACTIVITIES OF ACADEMIC LIBRARIES DURING THE LOCKDOWN PERIOD - LEGAL CONDITIONS IN POLAND}

The functioning of academic libraries during the lockdown period, understood as the period from about March 12 to the beginning of June 2020, was regulated by legal acts published by the Ministry of Science and Higher Education (MNiSW), the Ministry of Health, the Ministry of Development, as well as by the recommendations of the National Library and internal procedures and decisions of university authorities based on central guidelines.

On March 11, 2020, the Ministry of Science and Higher Education, following the recommendation of the Government Crisis Management Team, decided to introduce measures to prevent the spread of the COVID-19 virus in higher education institutions (MNiSW, 2020a). Classes at universities were suspended from March 12, at the same time indicating that scientific activities were to be continued. On March 16, 2020, in connection with the introduction of further restrictions by the Government of the Republic of Poland, the Ministry of Science and Higher Education published a new recommendation on "considering work restrictions by university employees, including non-academic teachers", in particular regarding the use of remote work in conjunction with the on-call system and limited access to buildings on the campus. On the same day, another information was published on the website of the Ministry of Science and Higher Education regarding the exemption from the obligation to work at the university, except in cases where it was necessary to ensure the continuity of the university's operation (MNiSW, 2020b). The aforementioned guidelines on remote work, on-call duty or release from work obligations had a direct impact on the way of organizing library activities during the lockdown period.

The announcement of the epidemic in Poland (MZ, 2020) on March 20, influenced further decisions on the operation of the school system: 
first the functioning of the university was suspended until April 10, then April 26, and finally May 24. In the meantime, on April 28, the Ministry of Development published extensive Guidelines for the functioning of libraries during the COVID-19 epidemic in Poland (MR, 2020), which included recommendations for ensuring the safety of library employees and staff, security in buildings, and procedures for dealing with suspected coronavirus infection. On May 22, 2020, the Ministry of Science and Higher Education provided information about the gradual lifting of restrictions on the activities of universities, among other things regarding the introduction of exceptions where necessary to the principle of distance learning. Guidelines were also published to help in the development of new university procedures, which were approved by the Chief Sanitary Inspector and which were to ensure safe functioning in the event of a threat of infection with the SARS-CoV-2 virus (Ministry of Science and Higher Education, 2020c). As far as the operation of libraries is concerned, these guidelines were based on the recommendations of the Ministry of Development of April 28 (MR, 2020) and stressed the need to: limit the number of people entering buildings, equip librarians with personal protective equipment, i.e. masks and gloves, "introduce a system of online lending to limit contacts between borrowers and library employees" and create conditions for contact-free reader service, and enforce obligatory hand disinfection and the use of gloves. At the beginning of June 2020, despite the fact that teaching at universities was still based on remote technologies, academic libraries, taking care of compliance with the sanitary regime and ensuring safety, gradually began to open up to users again. Various solutions were adopted, but in most cases the following precautions and safeguards were implemented: limiting the number of people in the building and/or separating some rooms as an open zone, equipping the direct user service stations with Plexiglas protection, introducing the obligation for readers to wear masks and disinfect hands, subjecting books to quarantine for several days, frequent airing of rooms and disinfection of worktops, equipping librarians with masks, gloves, visors, changing opening hours, restricting access to computer stations, etc.

\section{ORGANIZATIONAL FLEXIBILITY OF ACADEMIC LIBRARIES DURING THE LOCKDOWN PERIOD - THE AUTHOR'S OWN RESEARCH}

The study, the subject of which was the functioning of Polish academic libraries during the lockdown period (understood as the period from about March 12 to the beginning of June 2020), was carried out using the sociological method of a survey as a research tool. The on-line survey, to- 
gether with an invitation to participate in the research, was published on the discussion list of the Conference of Directors of Polish Academic Libraries, drawing on directors of academic libraries. It was also sent to the libraries of the top ten non-public universities according to the Perspektywy 2019 Ranking, in order to collect data from the directors of libraries of non-public universities. The data collection period was June 29 - July 10, 2020. 37 correctly completed questionnaires were obtained (a return rate of $30 \%$ ), which makes it difficult to consider the survey results representative for all academic libraries in Poland. However, the information obtained and the collected conclusions provide a broad insight into the principles of functioning of Polish academic libraries during the lockdown period and their organizational flexibility, and can offer an interesting voice in the discussion on the operation of academic librarianship in the reality of VUCA.

\section{CHARACTERISTICS OF THE RESEARCH SAMPLE}

As mentioned, 37 respondents (directors) from academic libraries in Poland took part in the survey. At this point, it is worth mentioning the number of people employed in the surveyed institutions, as in many situations it affects management strategies and the ability to flexibly adapt to the environment. The study thus represents establishments diversified in terms of the number of employees (see Chart 1). The largest percentage (43\%) were academic libraries employing $16-50$ people, every fourth $(24 \%)$ employs up to 15 people, $11 \%$ were large libraries with over 100 employees. As for the form of ownership, $84 \%$ of the surveyed information services were entities operating at public universities.

\section{Size of surveyed libraries - number \\ of employees}

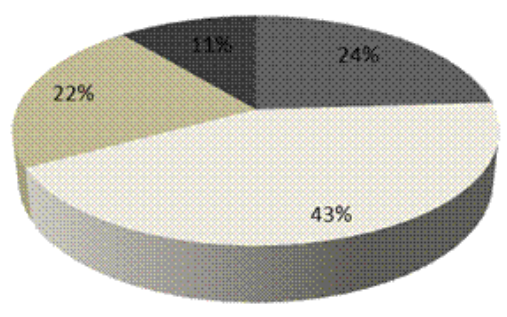

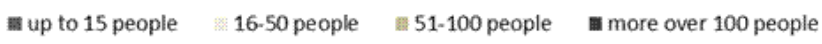

Chart 1. Size of the surveyed libraries in terms of the number of employees. 
The survey shows that $89 \%$ of academic libraries were operational during the discussed period. However, the activity was limited, both in terms of the type of services provided and the periods in which they were available. $11 \%$ of the surveyed units were completely closed to users.

\section{WORK MODE AND ORGANIZATIONAL FLEXIBILITY}

The fact that academic libraries provided services to users during the lockdown period is in itself a confirmation that there were some changes in their organization and flexible adaptation to the existing situation. Chart 2 shows the range of services that were provided to the academic community. It is impossible not to notice - understandable during the lockdown period - the shift of emphasis from traditional to electronic services. However, it is worth noting the activities aimed at extending this access, also by purchasing new licenses, as well as the emergence of new forms of services, such as digitization on request or the organization of remote events for users. In the open question, the respondents also mentioned other forms of activity, such as active involvement of librarians in interdisciplinary university teams for distance learning or strengthening cooperation with educators in the selection of electronic sources.

\section{Services provided by academic libraries}

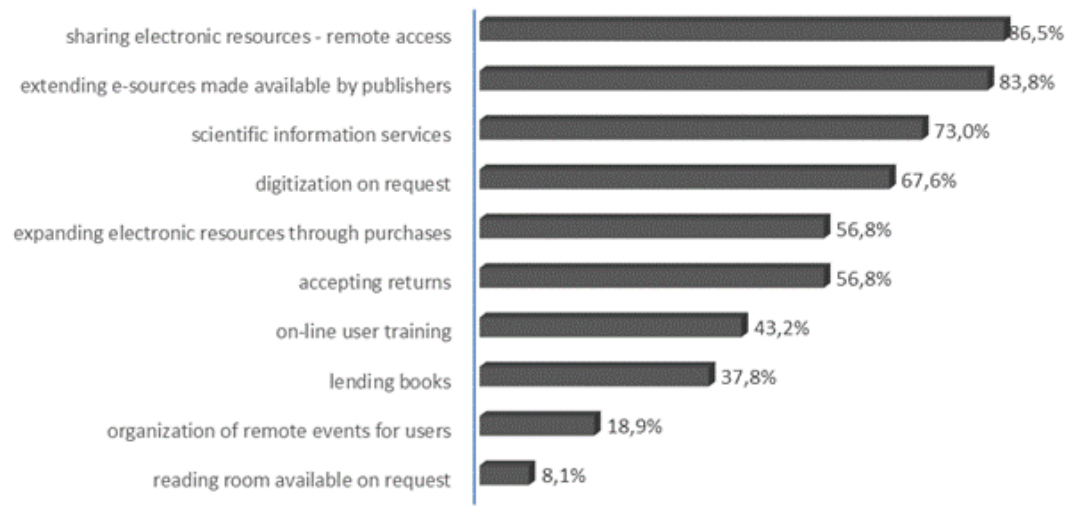

Chart 2. Services provided by academic libraries during the lockdown period. Source: Author's own study, 2020.

Organization of processes, ability to predict activities, risk estimation, rational use of resources and effective division of tasks, as well as awareness of control and impact on the course of events, both for managers and employees, are the undoubted advantages of having a plan and following 
its guidelines. However, persistently and unreflectively sticking to the plan can also have negative effects. The survey therefore asked directors of academic libraries how activities during the lockdown period had been organized and planned. It turns out that basically all libraries (97\%) had an action plan, but in the vast majority it was created on an ongoing basis according to the current situation. So there was something like "just in time" planning. The uncertain and unpredictable reality of the COVID-19 epidemic meant that any long-term planning was out of the question.

\section{Was there an action plan?}

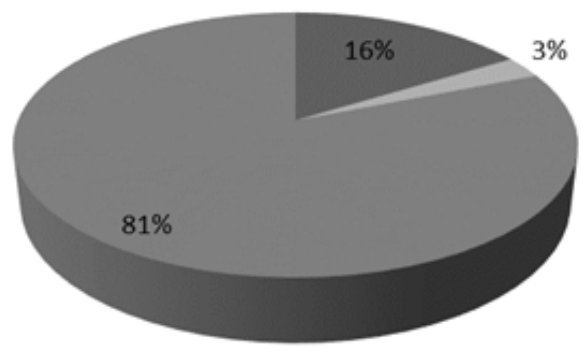

ayes $=$ no plan was created based on the current situation

Chart 3. Action plan of academic libraries during the lockdown period.

Source: Author's own research, 2020.

Organizational flexibility in academic libraries may be manifested in the reorganization of the organizational structure, changes in responsibilities, changes in decision-making processes, or in the approach to plans and procedures. These issues, among others, were the subject of this research.

When it comes to decision-making processes, more than half of the directors (54\%) admitted that as part of the rector's recommendations regarding the functioning of the entire university during the pandemic, they could independently decide on the rules of library operation. Almost 38\% could manage their libraries themselves, but to a very limited extent. In only $8 \%$ of cases the directors had nothing to say. This result confirms the fact that it is difficult to treat the library like other administrative units, and so it is good that the directors had been left independent in this matter. 


\section{Decision-making processes inside the library}

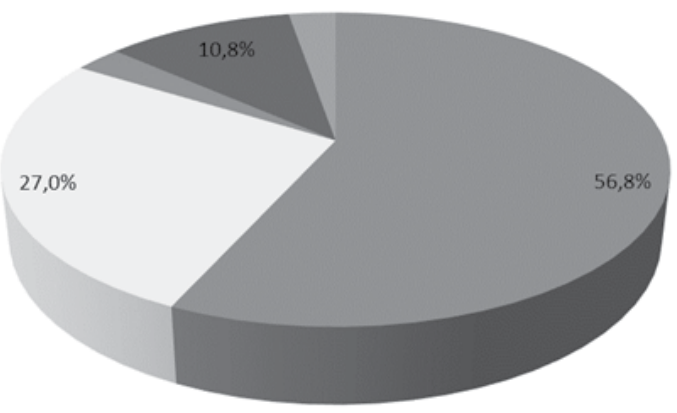

a decisions were made in the same manner

managers have been more involved in decision-making processes

Employees have been involved to a greater extent in decision-making processes

mployees have been involved to a greater extent in decision-making processes

managers participated in decision-making processes to a lesser extent than before

Chart 4. Decision-making processes in academic libraries during the lockdown period. Source: Author's own research, 2020.

And how were the decision-making processes carried out inside the library? Have they changed from before the lockdown? The analysis of responses to the question concerning making executive decisions shows that most libraries (57\%) did not introduce changes in this area. But it is impossible not to notice the fact that in the remaining part of the surveyed libraries there were modifications in this matter: in every fourth library $(27 \%)$ managers were more involved in decision-making processes, and in $11 \%$ they were excluded from this process. A closer look at the results shows that the changes in decision-making processes were mainly introduced in smaller libraries, employing up to 50 people. The previous decision-making system was maintained in larger libraries.

However, while changes in decision-making processes took place but were not a common phenomenon, when it comes to changes in the scopes of duties, the external situation forced specific actions in this regard. As it turns out, in $73 \%$ of cases changes were made to the scope of duties. Interestingly, the vast majority of this happened in an informal manner. 


\section{Were there changes in the scope of responsibilities?}

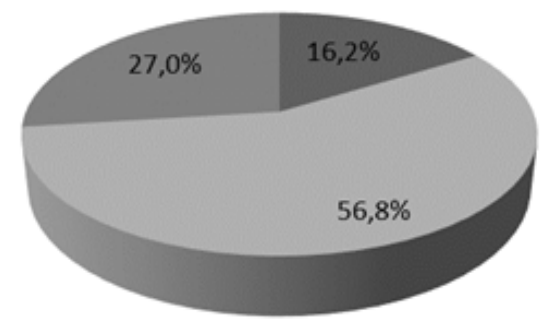

mes $\quad$ yes but not formally $\quad$ no

Chart 5. Changes in the responsibilities of academic librarians during the lockdown period. Source: Author's own research, 2020.

Changes in the scope of responsibilities were forced, among other things, by the need or requirement to assign remote work to librarians whose traditional duties could not be transferred to the virtual space (e.g. warehouse workers, direct reader service). Remote work is another manifestation of the organizational flexibility that has become quite common in libraries due to lockdown. Similar is a rotational system of work, in which remote work, on-call duty in the library, and "readiness", i.e., no work performed for the employer, are alternated.

The research shows that the most common organizational solution was either rotational work in which librarians alternately worked remotely and were on duty in the library - this was used in over $78 \%$ of cases - or remote work only $(62 \%)$, where no roster was used. In a few cases, also confirmed by an analysis of the answers to the next question, there was a "state of readiness" maintained.

\section{Mode of operation}

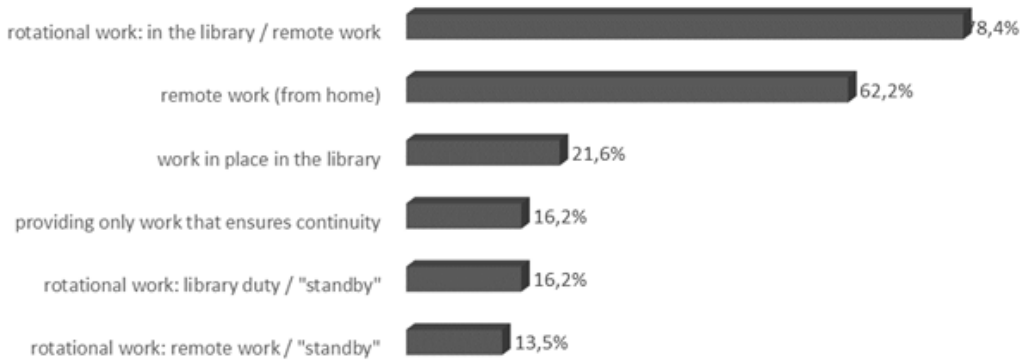

Chart 6. Mode of operation in academic libraries during the lockdown period. 
"Standby" is a new phenomenon that has arisen in academic libraries in connection with the lockdown. The possibility of its introduction was given by the Regulation of the Ministry of Science and Higher Education of March 16, 2020 on "limiting the obligation to perform work by university employees in their area, except for cases where it is necessary to ensure the continuity of the university's operation" (MNiSW, 2020b). The research analysis shows that this solution (otherwise questionable in terms of a fair division of labour and negatively influencing the motivation of the entire team) was used, but not in a common way. In almost half $(48.6 \%)$ of the libraries there was no "standby", and in the remaining cases it covered only a few people: up to $10 \%$ of the staff ( $27 \%$ of responses), and $11-25 \%$ of the staff (13.5\% of responses). Not surprisingly, "standby" was much more frequent in larger libraries employing over 50 people.

\section{"Standby" in academic libraries}

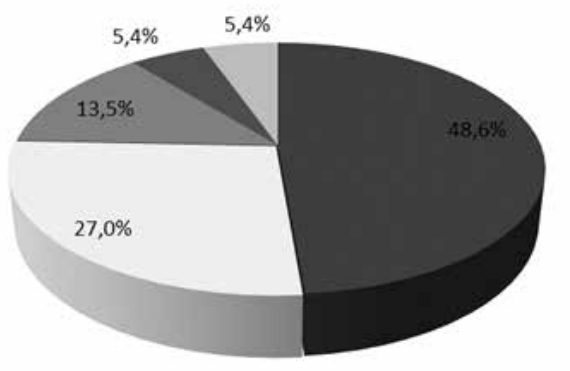

\footnotetext{
- there was no standby, all employees had assigned tasks

a few people were on standby (up to $10 \%$ of the crew)

a11-25\% of the crew were on standby

- $26-40 \%$ of the crew were on standby
}

Chart 7. "Standby" in academic libraries during the lockdown period.

Source: Author's own research, 2020.

Managing such a dispersed team of employees is not easy. You can fall either into the trap of excessive control, or - counting on the maturity and honesty of your subordinate employees - give up monitoring, and thereby lose access to up-to-date information on the progress of work. How was the control of tasks, performed remotely or in rotation by librarians, performed during the lockdown period? Very different solutions, adequate to organizational and cultural conditions, were used. It is difficult moreover to point to a clear dominance of one of them, especially since several different options were often used simultaneously. Thus systematic remote meetings were held in libraries as well as monitoring via computer systems. As for frequency, control was usually carried out once a week or ir- 
regularly depending on the decision of the supervisor. It can be concluded that the methods of control were adapted to the individual conditions prevailing in specific libraries. It is worth adding that when answering the question about the forms of exercising control, one could choose the phrase: "control was not exercised" - however, no respondent indicated this answer.

\section{Maintaining control}

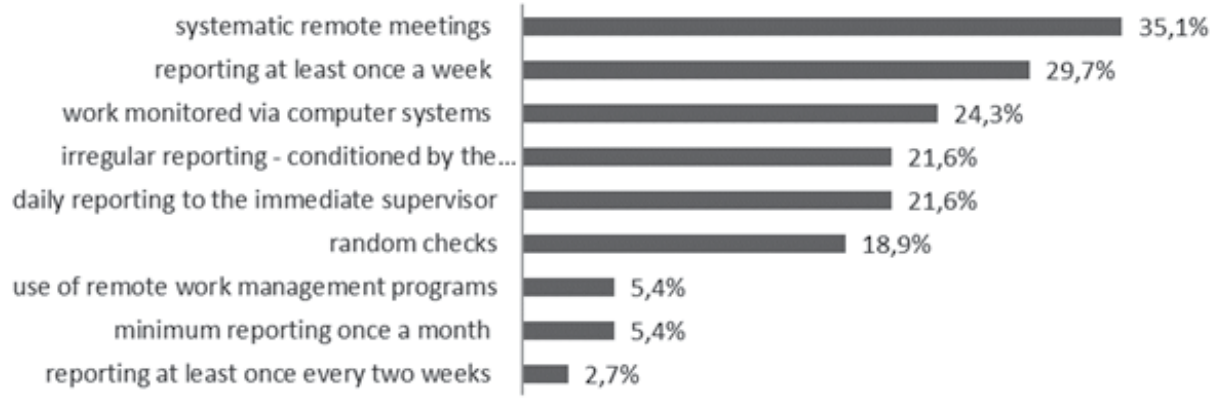

Chart 8. Controlling work in academic libraries during the lockdown period. Source: Author's own research, 2020.

\section{REMOTE WORK}

Remote work (telework, home office) - is an organizational solution that has rarely been used in library practice so far. Despite its advantages (e.g. the ability to reconcile work and family life, greater commitment and flexibility, time savings resulting from the absence of travel to work, greater loyalty, and less stress), it also has many disadvantages, e.g. the need to independently plan and organize the day, lower productivity and efficien$\mathrm{cy}$, limited access to the resources of the organization, lowering the comfort of living, limited contact with colleagues, technical difficulties, depreciation of remote work as "sitting at home" (Dolot, 2020. p. 37). Lockdown, however, forced directors and librarians to switch to this mode of work. How was it dealt with? What tasks were carried out in this regard? What was the issue of procedures, equipment and IT support? These issues were also the subject of the research. 


\section{Tasks performed as part of remote work}

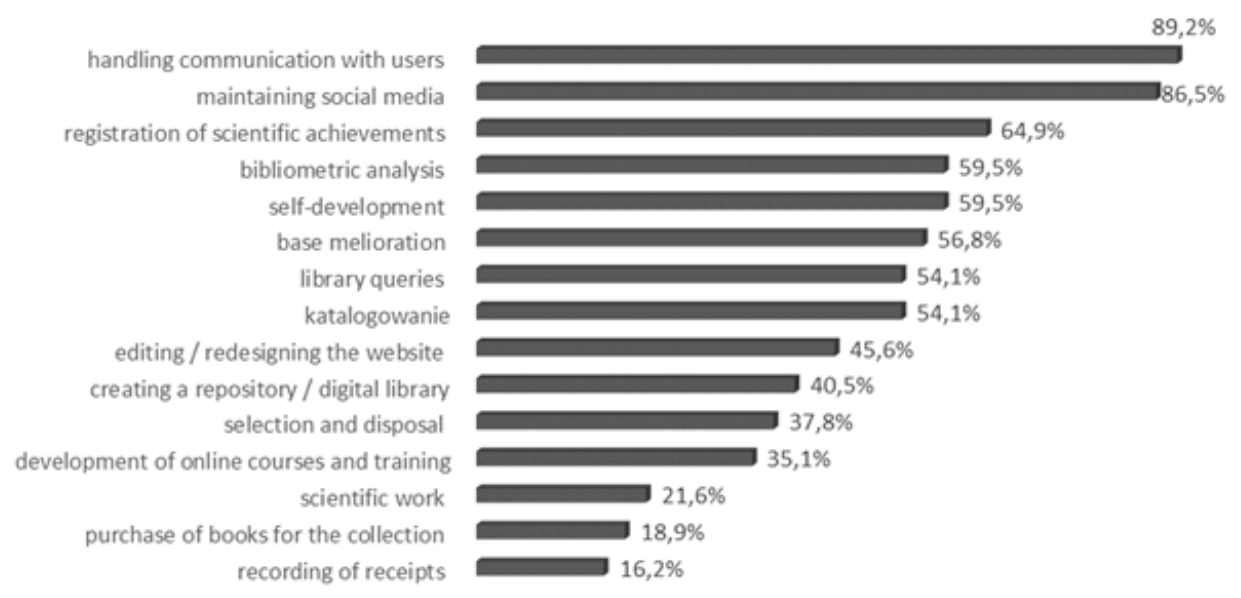

Chart 9. Tasks performed as part of remote work in academic libraries during the lockdown. Source: Author's own research, 2020.

The most common tasks performed remotely were handling communication with users $(89 \%)$ and maintaining a library's profile in social media $(86.5 \%)$. Not surprisingly, scientific information was also conducted remotely: the scientific achievements of researchers were recorded (including the preparation of data for migration in the new Polish Scientific Bibliography system), bibliometric analyses were conducted, and queries were carried out. Interestingly, the "self-development" of employees was also widely practiced. Chart 9 shows the wide range of tasks performed through remote work - many of them, as suggested by the answers in the open question, are new tasks, assigned to employees who so far had not had it in their scope of duties. Analysing the results of the study, it can be concluded that the organization of remote work to such a large extent and in such a wide, unprecedented scope confirms the organizational flexibility of academic libraries.

How was remote work organized? It is not surprising that the vast majority of librarians (54\%) who performed their professional duties in this way did it using their own computer equipment. In 19\% of cases, all employees worked on their own equipment, and business equipment was used to a similar extent (18\%). It is worth adding that there were libraries that provided their employees not only with equipment, but also the possibility of purchasing an additional data transfer package.

In terms of ensuring the security of information processed remotely, more than half of the libraries (51\%) relied on already existing procedures. In every fourth library, the existing procedures needed updating. 


\section{Procedures ensuring security of information}

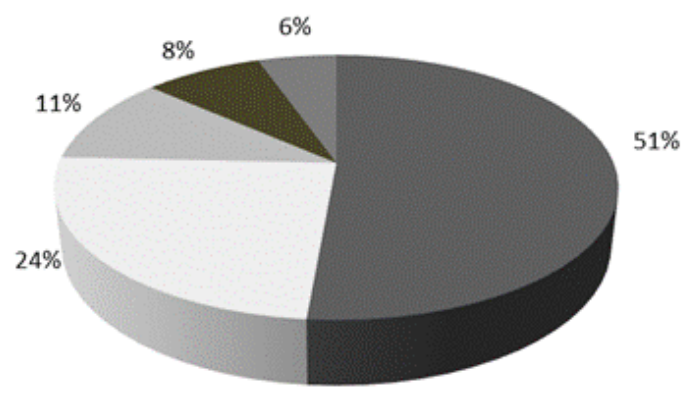

a procedures were in place before the pandemic and were sufficient

procedures were in place before the pandemic but had to be updated and adapted to the current situation

= procedures were developed on an ongoing basis in line with the developing situation

a there were no procedures in place and so far there are none

= there were no procedures, work was undertaken on them after the pandemic

Chart 10. Procedures ensuring security of information processed remotely in academic libraries during the lockdown.

Source: Author's own research, 2020.

What IT solutions were used when working remotely? The most popular solutions used in over half of libraries were access to library websites and servers by a VPN client (59\% of responses), and access to websites via a remote desktop (54\%). Cloud-based solutions were also used (40\%), and offline work was organized in manner resembling the putting-out system, being then "ripped" to the systems in the library (19\%). The vast majority of librarians had IT support: it was provided either by a library IT specialist $(49 \%)$ or by the university's IT department $(40 \%)$.

When describing work modes, it is also worth describing the ways in which employees communicate with each other and with the management. Organizing work in a dispersed and changing work environment is not easy. It turns out that the most commonly used were e-mail, as well as telephone contact (see Diagram 11). In $41 \%$ of the libraries surveyed, commercial communication applications were purchased, and in every fourth free external programs were used. The application names given in the open question are as follows: MS Teams, Zoom, Slack, Big Blue Button, Google Meet. It is worth adding that in the questionnaire one could also choose the answer: "maximum limitation of information flow" - but none of the respondents did so. This confirms the fact that the methods of com- 
munication were efficiently adapted to the situation, and communication itself was not limited.

\section{Methods of communication}

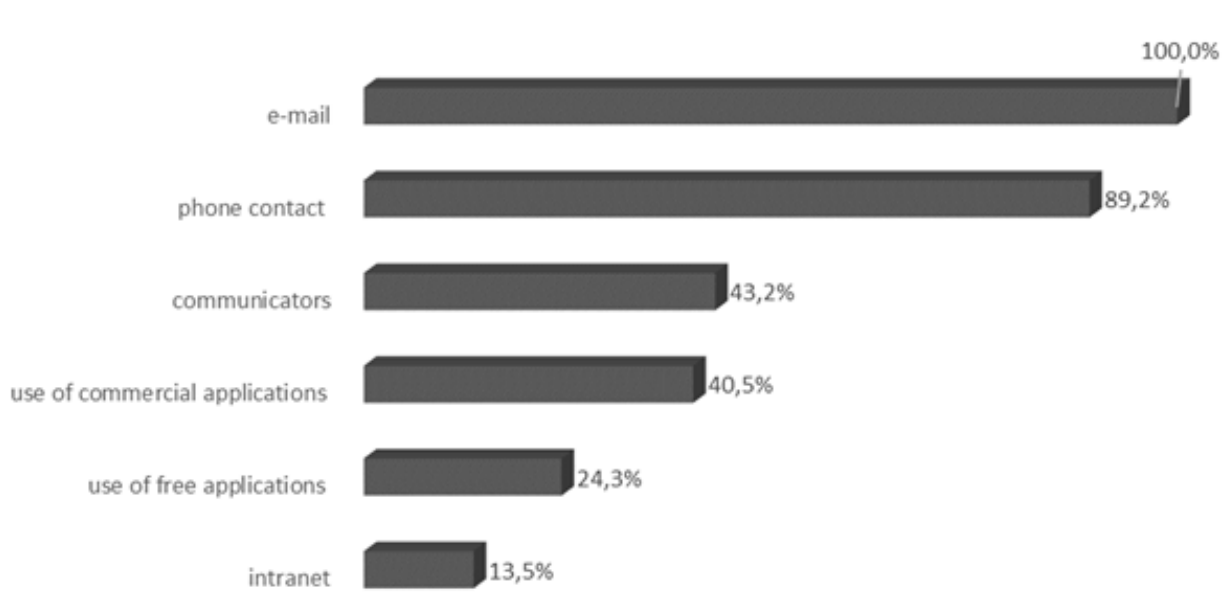

Chart 11 Means of communication of academic librarians during the lockdown period. Source: Author's own research, 2020.

\section{PROBLEMS AND CHALLENGES FOR THE FUTURE}

What was the biggest problem for university library managers during the COVID-19 epidemic? Chart 12 presents the phenomena which, in the opinion of the directors, occurred always, very often and often. It turns out that it was not easy to quickly create new rules and procedures for action $(65 \%)$ and there was often an inability to plan long-term activities $(59.5 \%)$. That is to say, the phenomena "typical" of the VUCA reality, which most managers and management organizations in the country and in the world must have encountered. When it comes to issues more specific to the librarian community, difficulties were indicated with assigning tasks to be performed remotely and awareness of the unfair division of work between librarians ( $46 \%$ each). Human issues related to employees' motivation and control were also problems for management during the lockdown period, which was pointed out by the respondents. Emotional instability of employees was also on the list of encountered difficulties this is all the more important because, according to the study, most of the libraries surveyed $(78 \%)$ did not provide psychological help for employees. In the open question, directors additionally emphasized the perceived lack of direct contacts with employees ("social and emotional ties"). Other problems mentioned by the respondents include lack of flexibility of database and electronic platform distributors in terms of extending access and copyrights inadequate to the current situation. 


\section{Difficulties in management}

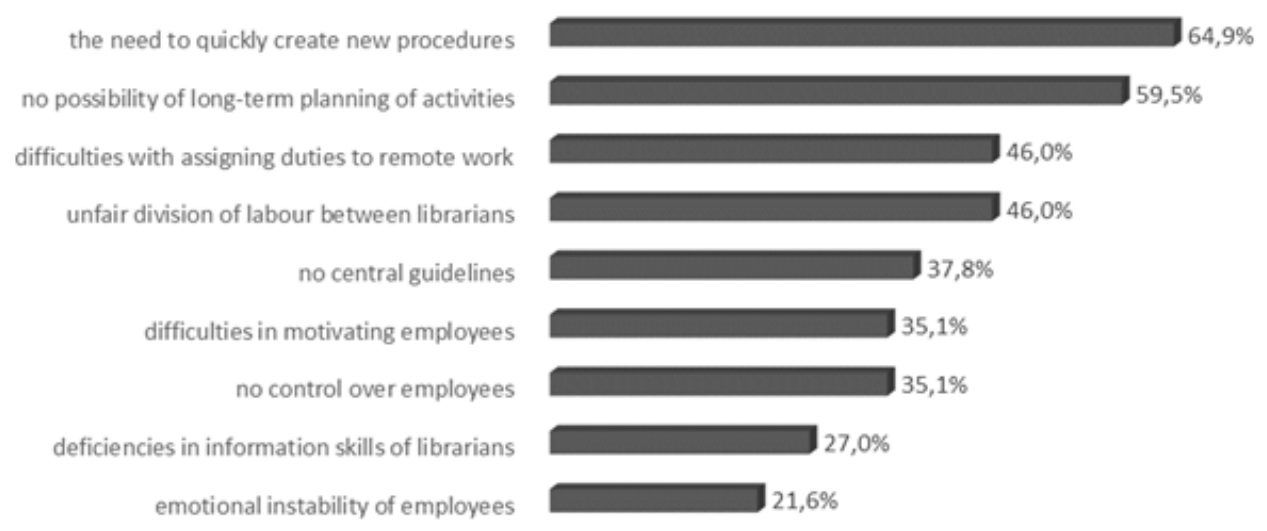

Chart 12. Problems and difficulties in managing academic libraries during the lockdown period. Source: Author's own research, 2020.

The fact that the libraries operated during the lockdown period, providing the academic community with necessary knowledge and information, confirms that despite the aforementioned difficulties and barriers, the problems have been overcome. How do the directors perceive this time and the "lessons in management" they have undoubtedly received from the reality of VUCA? Are there solutions that have proven successful and which are likely to be used to a greater extent in the future? Chart 13 presents those practices whose probability of implementation in the future on a scale of 1-5 (where 1 means not at all, and 5 for sure) was determined to be 3, 4 and 5. Remote work has undoubtedly proved successful, which is also confirmed by additional comments that directors shared in an open-ended question, as well as a task-oriented approach to performing tasks in the workplace. Implementation of these practices is predicted by over $62 \%$ of respondents. Organizational flexibility, which may scare one a little and generate resistance at first, and which in practice works well in a changing environment, has also, according to the respondents (49\%), a great chance for the future. Certainly, IT tools and solutions should also be developed ( $57 \%$ of responses) to facilitate remote implementation of tasks and the flow of information and documents. The directors also noted the importance of tightened cooperation between librarians and academics in the preparation of teaching materials and research facilities. Interestingly, the decision-making process changed under the influence of the COVID-19 epidemic also has a chance to remain a permanent fixture in selected academic libraries. 


\section{What management practices will be used in the future?}

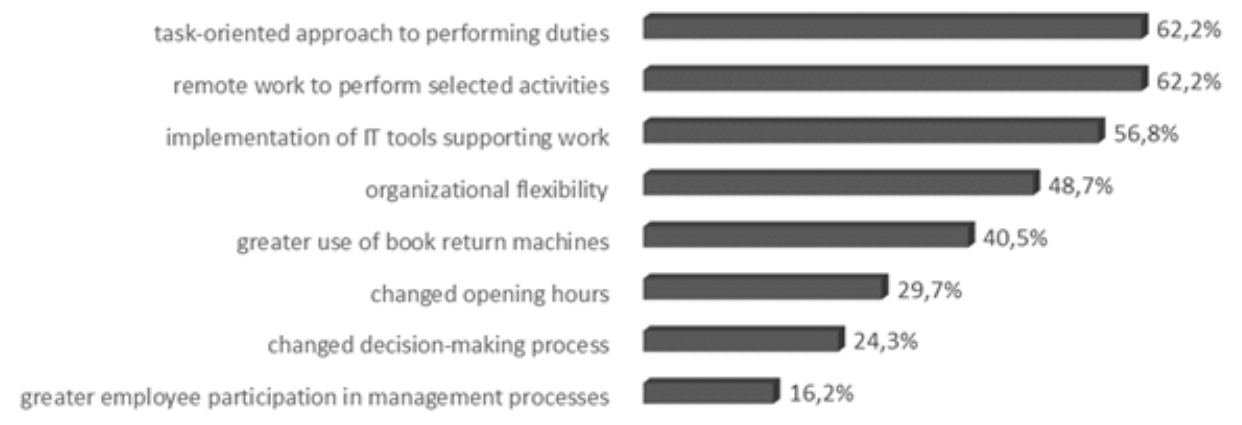

Chart 13. Management solutions in academic libraries from the lockdown period that have proved successful and may be used in the future.

Source: Author's own research, 2020.

Finally, it is worth quoting a few statements of the directors of academic libraries on the management experiences gained during the lockdown period:

- "A lesson in effective management, often without the support of superiors. Quite a lesson in humility towards employees' fears, without showing one's own weaknesses and fears.

- "Need for quick and specific decisions and reactions to emerging problems as well as anticipating possible problems."

- "There are staff reserves in the library. The library continues to have excess employees."

- "The threat of coronavirus forced us to change the work system, solve problems creatively, react quickly to new needs, re-evaluate current organizational solutions, rethink how to manage the team, how to communicate with the team."

- "One can't ignore emotions."

- "It is necessary to have clear and precise delegated tasks and control of their implementation. Employees need constant contact with their superiors."

- "Remote work is possible in a library, $50 \%$ of the team can work from home permanently, only direct user service requires staff presence. Purchasing, cataloguing, database control, bibliometrics, scientific information - all of this can be done remotely."

- "Predict the development of the remote work platform in the future budget. 2. Plan the purchase of an external automatic book return machine. 3 Amend the agreement with PKN, thus ensuring remote access to the subscribed standards." 
- "The need to change the organization of free access collections and the methods of making them available, any facilitations in electronic access, creating an educational base founded on electronic copies of documents, adapting the library's tasks to distance learning."

The research analysis shows that the directors of academic libraries efficiently dealt with the management of institutions in the real VUCA. Despite the emerging problems of an organizational (procedures and principles of operation), technical (ensuring appropriate hardware and software) and human (fair division of labour, optimal control system, empathy and care for employees) nature, it was possible to lead academic libraries through the difficult period of lockdown - and allow users to access research and teaching materials. Academic libraries have demonstrated organizational flexibility in the following areas: extending the scope of services, organizing a rotational system of work and performing tasks remotely, changing responsibilities, planning "just in time", and in some cases modifying decision-making processes. Many of these practices have a chance to be used in the future, which only confirms their effectiveness and the openness of directors to the use of new and effective solutions.

What could continue to be a problem and where should the emphasis be to find an appropriate solution? In addition to legal and financial problems, such as inadequate copyright, limited resources for the purchase of electronic sources, the lack of automated book return or electronic platforms for information management, it is worth paying attention to issues related to human resource management. The unfair separation of remote work, limiting the "standby state", refining the system of informing, controlling, and motivating employees - certainly these problems still need to be addressed in the future.

\section{SUMMARY}

The reality of VUCA related to the emergence of the COVID-19 epidemic and the nearly 3-month lockdown ordered by the state authorities put managers, as well as employees of companies and institutions, very much to the test. In academic libraries, until now operating in a fairly predictable, as well as standardized and structured environment, the need to adapt to the environment so quickly and flexibly was in fact a completely new phenomenon. The analysis of the research results shows that academic libraries to a large extent were able to adapt to the situation, and also - what is equally important - to draw appropriate conclusions from this lesson.

The libraries examined showed a lot of organizational flexibility, which manifested itself in planning "just in time", introducing remote work and rotational work systems, changing scopes of duties, extending the scope of 
services, as well as using IT tools (also free ones) to organize and monitor work. Moreover, the directors see the need to refine the communication system and implement additional IT solutions, and they also see the fact that many of the current operating practices no longer exist and should be changed (e.g. delegating tasks to remote work, eliminating excess employment). These activities are in line with the "Vuca Prime" model developed by Bob Johansen from the Institute for the Future, in which it is recommended that organizations in response to the evoked VUCA phenomena acquire the following set of skills: Vision, Understanding, Clarity and Agility. A clear vision in place of a detailed and rigid plan; the manager's ability to obtain a variety of feedback from the environment (employees, customers, suppliers) as a response to uncertainty; clarity, i.e. reliably developed tasks and processes and providing information helpful in making decisions in response to the complexity of phenomena, as well as flexibility and agility manifested in recognizing situations using experiments and tests, combined with the ability to quickly adapt and implement changes (Johansen, 2017). The set of these features, also referred to as VUCA 2.0 (George, 2020) (in the VUCA 2.0 model, instead of Clarity, it is often referred to as Courage, manifested in taking risks and boldly applying decisive movements and solutions), is considered the basis of modern leadership in the variable and unpredictable reality.

Time will show whether the organizational flexibility demonstrated by academic libraries during the lockdown was only a "brilliant improvisation", or whether it will be a feature that will permanently enter the organizational culture of libraries and institution management strategies, and will also be a manifestation of organizational learning in how to effectively function within the VUCA reality.

\section{BIBLIOGRAPHY}

Ali, Muhammad Yousuf; Gatiti, Peter (2020). The COVID-19 (Coronavirus) Pandemic: Reflections On The Roles Of Librarians And Information Professionals. Health Information and Libraries Journal, 37 (2), 158-162.

Dolot, Anna (2020). Wpływ epidemii CoOVID-19 na pracę zdalną - perspektywa pracownika. e-mentor, no. 1 (83) pp. 35-43.

Elastyczność struktury organizacyjnej (2019). [In:] Leksykon zarzadzania i marketingu w bibliotekoznawstwie, M. Wojciechowska et al., Warszawa: Wydaw. SBP, p. 66.

George, Bill (2017). VUCA 2.0: a strategy for steady leadership in an unsteady world. Forbes [online] February [access: 20.08.2020]. Available at WWW: $<$ https://www.forbes.com/sites/hbsworkingknowledge/2017/02/17/vuca-2-0-astrategy-for-steady-leadership-in-an-unsteady-world/\#2658a33013d8>

Haricombe, Lorraine J.; Lusher, T. J. ed. (1998). Creating the agile library: a management guide for librarians. Westport: Greenwood Press. 
Johansen, Bob (2017). Leaders make the future: ten new leadership skills for an uncertain world. San Francisco: Berrett-Koehler.

Judek, Rafał (2020). Przywództwo transformujące w świecie VUCA. Production Manager [online] Kwiecień [access: 15.08.2020]. Available at WWW: <http:// www.production-manager.pl/2020/04/14/przywodztwo-transformujace-wswiecie-vuca/>

Krawczyńska-Zaucha, Tatiana (2019). A new paradigm of management and leadership In the vuca Word. Scientific Papers Of Silesian University Of Technology. Organization and Management Series, no. 141, pp. 221-230.

Manifest programowania Agile (2001). [online][access: 20.08.2020]. Available at WWW: <http://agilemanifesto.org/iso/pl/manifesto.html>

MNiSW (2020a). Rozporzadzenie Ministra Nauki i Szkolnictwa Wyższego z dnia 11 marca 2020 r. w sprawie czasowego ograniczenia funkcjonowania niektórych podmiotów systemu szkolnictwa wyższego i nauki w zwiazku z zapobieganiem, przeciwdziataniem i zwalczaniem COVID-19. Dz.U. 2020 poz. 405 [online]. Ministerstwo Nauki i Szkolnictwa Wyższego, [20.08.2020], https://isap.sejm.gov.pl/isap.nsf/ DocDetails.xsp?id=WDU20200000405

MNiSW (2020b) Rozporzadzenie Ministra Nauki i Szkolnictwa Wyższego z dnia 16 marca 2020 r. zmieniajace rozporzadzenie w sprawie czasowego ograniczenia funkcjonowania niektórych podmiotów systemu szkolnictwa wyższego i nauki w zwiazku z zapobieganiem, przeciwdziałaniem i zwalczaniem COVID-19. Dz.U. 2020 poz. 455 [online]. Ministerstwo Nauki i Szkolnictwa Wyższego, [access: 20.08.2020]. Available at WWW: <http://isap.sejm.gov.pl/isap.nsf/DocDetails.xsp?id=WDU20200000455>

MNiSW (2020c). Środowiskowe wytyczne w zwiazku z częściowym przywracaniem działalności uczelni [online]. Ministerstwo Nauki i Szkolnictwa Wyższego, [access: 20.08.2020]. Available at WWW: <https://www.gov.pl/attachment/add97c72-cd87-425c-a346-945524e59e09>

MR (2020). Wytyczne dla funkcjonowania bibliotek w trakcie epidemii COVID-19 $w$ Polsce, [online] Ministerstwo Rozwoju; Główny Inspektorat Sanitarny, [access: 20.08.2020]. Available at WWW: <https://www.gov.pl/web/rozwoj/biblioteki>

MZ (2020). Rozporzadzenie Ministra Zdrowia z dnia 20 marca 2020 r. w sprawie ogłoszenia na obszarze Rzeczypospolitej Polskiej stanu epidemii. Dz.U. 2020 poz. 49. [online]. Ministerstwo Zdrowia, [access: 20.08.2020]. Available at WWW: <http:// isap.sejm.gov.pl/isap.nsf/DocDetails.xsp?id=WDU20200000491>

Naeem, Salman; Bhatti, Rubina (2020). The Covid-19 'infodemic': a new front for information Professional. Health Information and Libraries [online], June [access: 15.08.2020]. Available at WWW: <https://doi.org/10.1111/hir.12311>

O'Connor, Steve (2015). Library management in disruptive times: skills and knowledge for an uncertain future. London: Facet Publishing, 2015.

VUCA (2020) In: Encyklopedia zarządzania [online] [access: 20.08.2020]. Available at WWW <https://mfiles.pl/pl/index.php/VUCA>

WHO (2018). Managing epidemics: key facts about major deadly diseases. [online] World Health Organization. [access: 16.08.2020]. Available at WWW: <https:// apps.who.int/iris/handle/10665/272442>

WHO (2020). Coronavirus disease 2019 (COVID-19) Situation Report - 101 [on- 
line] Word Health Organization [access: 15.08.2020]. Available at WWW: $<$ https://www.who.int/docs/default-source/coronaviruse/situation-reports/ 20200430-sitrep-101-covid-19.pdf?sfvrsn=2ba4e093_2>

Wojciechowska, Maja et al. (2018). Leksykon zarzadzania i marketingu w bibliotekoznawstwie. Warszawa: Wydaw. SBP, p. 66.

Worley, Christopher. G.; Jules, Claudy (2020). COVID-19's Uncomfortable revelations about agile and sustainable organizations in a vuca Word. The Journal of Applied Behavioral Science, vol. 56(3), pp. 279-283.

Ziębicki, Bernard (2010). Elastyczność jako kryterium efektywności organizacyjnej. Acta Universitatis Lodziensis. Folia Oeconomica, v. 234, pp. 387-396. 